\title{
WHAT IS THAT WHICH IS ALWAYS BECOMING, AND WHAT IS THAT WHICH ALWAYS IS? ${ }^{1}$
}

JOSÉ MARÍA ZAMORA CALVO, Universidad Autónoma de Madrid, Madrid, Spain

\author{
ZAMORA CALVO, J. M.: What Is That Which Is Always Becoming, and \\ What Is That Which Always Is? \\ FILOZOFIA, 75, 2020, No 3, pp. $237-250$
}

\begin{abstract}
This paper explores the Neoplatonic interpretations of the distinction that Plato draws at the beginning of Timaeus $(27 \mathrm{~d} 6-28 \mathrm{a})$ between "that which always is and has no becoming" and "that which is always becoming but never is". Philoponus tries to show that Plato understands "generated" in the sense of "generated in time", rejecting Aristotle's incompatible thesis. According to the Neoplatonic reading that Plotinus inaugurates, and Porphyry subsequently develops, "generated" ( $\gamma \varepsilon v \eta \tau o ́ v)$ has two meanings: to depend on a cause and to exist by virtue of a composition. The first meaning is assigned to the incorporeal - the Intelligence and the Soul; the two meanings, on the other hand, are assigned to bodies. The Intelligence depends on a cause, the One-Good; and, in turn, the Soul depends on a cause, the Intelligence. These realities are not in the range of "that which is always generated and never is", but of "that which always is and is not generated", i.e. of "that which is without ceasing to be".
\end{abstract}

Keywords: Plato - Timaeus - Neoplatonism - Becoming - Generated - Cosmology

The distinction that Plato establishes in Timaeus (27d6 - 28a1) between "that which



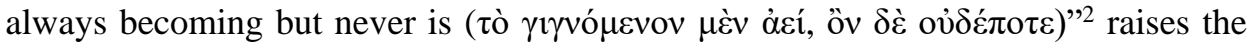
hypothetical alternative between the two possible models that the craftsman has before him to manufacture his work. But then the alternative is clarified: if one generated is chosen as the model, the result will never be beautiful, while if the eternal model is chosen, the work will be beautiful $(28 \mathrm{a}-\mathrm{b})$. That said, "that which is generated and destroyed" in some way is (Resp. V.477e - 478d), although it never truly becomes (Tim. 28a).

The changes involved in the notion of becoming - generation and corruption require the principle of causality to be used: Everything that is generated necessarily has a cause - this being understood in the sense of artisanal cause - and since the world is

\footnotetext{
${ }^{1}$ I would like to thank the anonymous referees for their invaluable comments and recommendations.

${ }^{2}$ Although the handwritten tradition remains very uncertain about it, and despite the controversy that has developed in recent years, we maintain, with Rivaud $(1925,140)$, the second ḋeí, the one

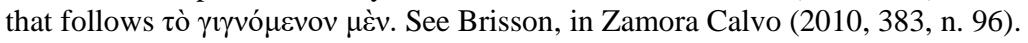


beautiful, the divine artisan or demiurge has produced it by looking at the eternal model, which is always identical, and not the generated model. The difference between the discourses referring to the eternal model and those referring to the copy of that model, that is to say, to the world, allows the following proportion to be established:

\section{be : becoming : truth : belief}

For Plato, becoming, that which is always generated, differs from the world for four reasons: (1) When Timaeus offers us a summary of the introduction of a "third



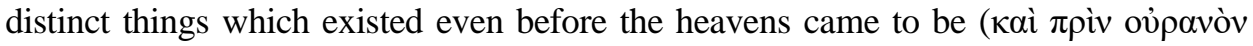

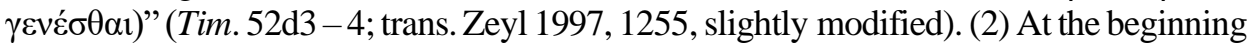
of his cosmogonic discourse, becoming is postulated as a hypothetical model for the generation of the world, even if it is a disregarded hypothesis (27d-28a). (3) Becom-

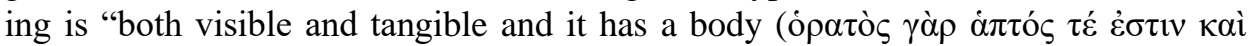
$\sigma \tilde{\omega} \mu \alpha$ है $\chi \omega v) "(28 b 7-8$; see 31b), while the world is not only corporeal, but also a living being that consists of a body and also a soul. (4) The demiurge "so he took over

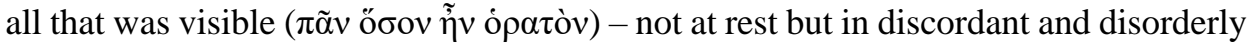

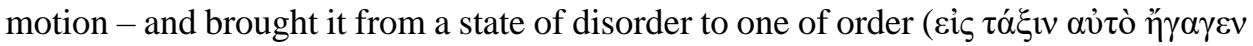
$\dot{\varepsilon} \kappa \tau \tilde{\eta} \varsigma \dot{\alpha} \tau \alpha \xi \dot{\imath} \alpha \varsigma)$, because he believed that order was in every way better (ö $\mu \varepsilon ı v o v)$ than disorder" (30a3 - 6; trans. Zeyl 1997, 1236). Therefore, by virtue of these four reasons, becoming, which by itself signifies disorder, differs from the world. Since what is generated, while not truly, is an object of opinion and is not intelligible, then causality is confined to the sensible.

In Timaeus, Plato distinguishes between two modes of apprehension, based on the radical ontological heterogeneity between being and becoming (27d5-28a4): (1) That which is born and perishes, that which always becomes another, can only be the object of sensible perception and of the opinion that comes from it; (2) that which always is and remains identical to itself, conversely, can only be grasped by intellec-

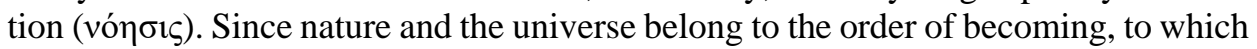
it never remains identical to itself but always changes, it is impossible for them to be the object of science. Therefore, by always becoming others, nature and the universe never are, because they do not belong to the order of what is.

\section{I.}

In On the Eternity of the World against Proclus (De aeternitate mundi contra Proclum), John Philoponus no longer defends the thesis of a doctrinal symphony between Plato and Aristotle, but argues that between both philosophers the disagreement prevails in the capital points. A part of this mature treatise - written around 529 - is precisely dedicated to a new key project in the development of his hermeneutical architecture: it seeks to snatch the authority of Plato from his pagan adversaries, showing that the text of the dialogues coincides more with the doctrines of the Christians. In Book VI of De aeternitate mundi contra Proclum (VI.27.211.18 ff.), after citing passages from Aristotle and Alexander of Aphrodisias about the eternity of the world, 
he seeks to show that Plato construes "generated" in the sense of "generated in time", rejecting Aristotle's incompatible thesis (Segonds 1992, 478).

In the eighteen books of his treatise De aeternitate mundi contra Proclum, Philoponus attacks the eighteen arguments that Proclus, in his On the Eternity of the World (De aeterniate mundi), uses to argue in favour of the eternity of the world and its incorruptibility. ${ }^{3}$ To undertake this refutation and establish that the world had a beginning, he especially relies on a literal interpretation of Plato, who would advocate a temporal genesis of the world. Similarly, to support his refutative hermeneutics against Proclus, he also turns to Aristotle, ${ }^{4}$ Alexander of Aphrodisias, Plutarch of Chaeronea, Atticus, Taurus, Ptolemy, Galen, Plotinus and Porphyry, in order to establish that the world had a beginning.

But Proclus's objections are not directed so much at Christians as at Middle Platonist philosophers who championed a literal interpretation of Plato. ${ }^{5}$ For his answers, in many passages, as Share (2005a, 1-6) points out, Philoponus adopts a clearly Christian point of view, and not just purely philosophical, referring to Scripture and the Fathers of the Church.

In Book VI, starting from chapter six (134.21 ff.), he seeks to definitively establish Plato's true theory about the eternity of the world and to refute pagan interpreters to remove Plato's authority from them.

In the first place, Philoponus comments on several Plato passages that address the theme of the generation of the world (chap. $7-8,135.21-144.15$ ), before going on to examine the Platonic commentators Taurus, Porphyry and Proclus (chap. $9-23$, 144.16 - 195.6), concluding that the solutions they propose are unacceptable, contradictory and based on an a priori thesis; finally, Philoponus exposes the authors who, according to his exegesis, teach Plato's true thesis: Plutarch, Atticus and Aristotle, whose passages he quotes accompanied by the comments dedicated to him by Alexander of Aphrodisias (chap. 28 - 29, 211.6 - 242.22).

But Philoponus does not directly quote Timaeus, as demonstrated by Segonds (1992, 466, who compares Tim. 35a - 36d with Philoponus's text De aeternitate

\footnotetext{
${ }^{3}$ Edition of the Greek text that preserves argument $2-18$ of Proclus' On the Eternity of the World against the Christians; argument 1 is only preserved in an Arabic translation (Rabe 1899 [1963]); German translation of the 18 arguments - argument 1 is translated by Heine - quoted in Philoponus' De aeternitate mundi contra Proclum, short notes and several emendations of Rabe's edition Baltes (1978, 134 - 164); English translation of the fragments from Philoponus' De aeternitate mundi contra Proclum, with commentary (Lang - Macro - McGinnis, 2001); English translation of the text of Philoponus that preserves Proclus' 18 arguments (argument 1 is translated by Adamson): Share (2005a, 2005b, 2010) and Wilberding (2006).

${ }^{4}$ See Gleede (2009).

${ }^{5} \mathrm{We}$ do not have sufficient elements to allow us to postulate that the recipients of Proclus's treatise were Christians, as established, without sound arguments, by Rosán (1949). Plutarch of Chaeronea and Atticus were the most likely recipients of his criticisms, following the refutation he had undertaken in his commentary on Timaeus. As regards our topic, the world was not born in time (Proclus, In Tim. I.381.26 - 383.12), according to the interpretation of Porphyry and Iamblichus (In Tim. I.382.12 - 383.22). See Mueller-Jourdan (2011, 55).
} 
mundi 196.25 - 197.15), but indirectly, through intermediate source(s), which include citations and summaries of passages from Plato's physical discourse.

Who are these intermediary commentators? "For those who are interested, a more detailed examination of these matters may be found in the earlier commentators ( $\pi \alpha \rho \grave{\alpha}$

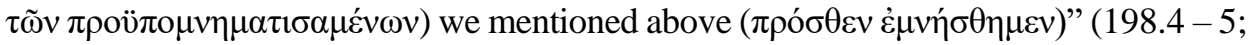

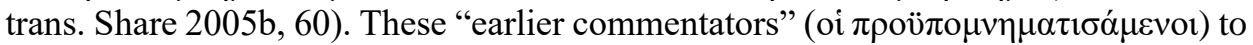
whom Philoponus refers in order to carry out a more detailed examination are identified in a previous passage: "For some of the earlier commentators on Plato, including the Platonist Taurus and Porphyry the Phoenician, whom Proclus too has followed, agree that Plato says that the world is generated ( $\gamma \varepsilon v \eta \tau$ òv), but not generated in the



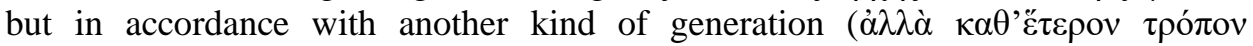
$\gamma \varepsilon v \varepsilon \dot{\varepsilon} \sigma \varepsilon \omega \varsigma)$; for they say that 'generated' has a number of meanings $(\pi \circ \lambda \lambda \alpha \chi \tilde{\omega} \varsigma)$ ", (145.1 - 8, trans. Share 2005b, 28).

To counter the adversaries of the temporal creation of the world, Philoponus uses Taurus's Commentary on Timaeus, or Porphyry's, or both, and could even have quoted an excerpt from one of these two authors whose work has not reached us.

That said, how do the Neoplatonic exegetes read Aristotle? Philoponus accepts an exegetical subterfuge designed by some Neoplatonists: If Aristotle attacks Plato, it is only apparently; in fact, he does so to attract the attention of the restless and dynamic reader, and show him that Plato's text encapsulates a profound sense different to the apparent sense.

Philoponus experiences what Verryckehn $(1991,213)$ describes as "total palinode"; but this profound and radical change could be related to the adoption of a manifestly Christian point of view. Verryckehn differentiates two Philoponus, one who remained faithful to the Neoplatonic teaching conveyed by Ammonius in the Alexandrian school, and for whom defending pagan philosophy and being a Christian were not mutually exclusive; and the other, a defender of Christianity at all costs, who supported the theses opposed to the first, among which is the eternity of the world, contrary to Christian teaching. After 529, Christian Neoplatonists had to suffer pressures and threats that would have forced them to renounce the teachings received from paganism. After his conversion to Christianity, Philoponus gradually renounced Platonic theses, in particular, the thesis of the "generation" of the world, key to a literal reading of Timaeus. The "total palinode" is exegetical, but he continues to use his own comments on the drafting of his treatises against the adversaries of the temporal creation of the world (De aeternitate mundi contra Proclum 199.22 - 200.3).

II.

For Proclus, Timaeus's discourse is a "scientific account" concerning the universe

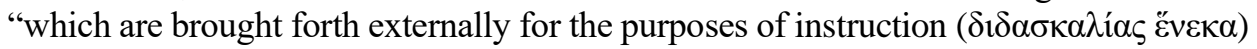
and social intercourse" (In Tim. I.218.19 - 20). It is, therefore, a $\delta 1 \delta \alpha \sigma \kappa \alpha \lambda$ iкò $\lambda$ ó $\gamma \circ \varsigma$ that exposes the birth of the world "scientifically and didactically" (I.218.26-27).

Proclus interprets the proposition "the world has been generated" as true, while revealing and communicating the true nature of the world, namely, that it is sensible 
and that it possesses its essence in time (In Tim. I.227.4 - 240.12 [ad 27d6 - 28a1]). In so doing, Proclus's "literal" exegesis of Timaeus opposes the "geometric" (nonliteral) interpretation advocated by members of the Old Academy, especially by Xenocrates. For Alcinous, the Middle Platonist philosopher of the second century AD, the birth of the world in Plato is an image, meaning that Timaeus's discourse is figurative and should not be interpreted literally. ${ }^{6}$

The influence of Iamblichus was probably crucial to the abandonment of the "geometric" interpretation by the Neoplatonic school.

"An alternative is that he supposed ( $\dot{\pi} \varepsilon \dot{\varepsilon \varepsilon \tau o) ~ t h a t ~ t h e ~ u n i v e r s e ~ i s ~ g e n e r a t e d ~}$

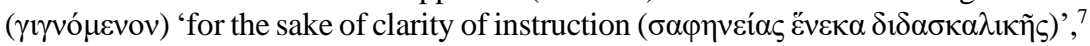
in order to teach how great the benefits are that it has received from the providence of the creator. This view is true as far as it goes, but it is not sufficient to do justice

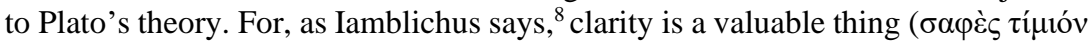

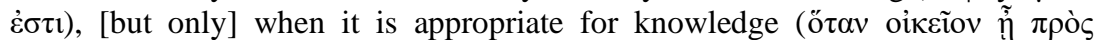
$\dot{\varepsilon} \pi \iota \tau \eta \dot{\mu \eta} v$ ), since, even in the case when the universe is said to be everlasting (ådóov), it would still be possible to show that the goods it possesses are given by the gods" (In Tim. I.290.9 - 16 [ad. $28 b 8$ - c2]; trans. Runia - Share 2008, 143). ${ }^{9}$

Proclus, therefore, reinterprets the formulation of the statute of the discourse as $\delta 1 \delta \alpha \sigma \kappa \alpha \lambda$ ikòs $\lambda$ ó $\gamma \circ \varsigma$, remaining true to the literal exegetical proposal that Iamblichus probably inaugurated to overcome the non-literal "geometric" interpretation. The scientific nature of the physical discourse is mainly due to the mathematician Timaeus, who remained faithful to the Pythagorean way of expression, undertaking the secure and "only way of science" (In Tim. I.223.5 - 15 [ad 27d5]). ${ }^{10}$

The Diadochus considered that the two "preliminary" sections of the physical treatise itself, corresponding to Timaeus $(27 \mathrm{~d} 6-28 \mathrm{~b} 5$ and $28 \mathrm{~b} 5-29 \mathrm{~d} 5)$, sought to establish the existence of the first causes of the world in order to thus provide the condition of possibility of a treatise of the demiurge. ${ }^{11}$

\footnotetext{
${ }^{6}$ See Alcinous, Didascalicus 32.32 - 35 (Whittaker - Louis 1990, 32).

${ }^{7}$ See Aristotle, De Caelo, I.10.280a1 - 2: "for didactic reasons ( $\left.\delta 1 \delta \alpha \sigma \kappa \alpha \lambda i \alpha \varsigma \chi \alpha ́ \rho ı v\right)$ facilitating understanding by exhibiting the object, like the figure, as in course of formation." See also Simplicius' comments on the Aristotelian passage (In Cael. 334.4).

${ }^{8}$ Iamblichus, Fr. 33 Dillon.

${ }^{9}$ See Baltes $(1978,51)$.

${ }^{10}$ See Lernould (2000, $\left.67-68\right)$.

${ }^{11}$ In In Tim. I.276.10 - 30, Proclus distinguishes two sections ("Hypotheses" and "Demonstrations"), which precede the treatise of the demiurge itself. See (Lernould 2000, 68, n. 16). According to the second, third and fourth general "hypotheses", which precede the treatise of the demiurgy itself: (1.b) "That which is 'become' is understood by the opinion accompanied by the irrational feeling" (Tim. 27d6-28a1 - 4). (2.a) "Everything that is 'become' 'becomes' from a cause". (2.b) "That which exists not from a cause is not "become" $(28 \mathrm{a} 4-6)$. Proclus assigns as the objective of the first two "hypotheses" - the definitions of that which is "eternal" and that which "becomes" $(27 \mathrm{~d} 6-28 \mathrm{a} 1-4)$ the discovery of the "generated" nature of the World (In Tim. I.235.32 ff.) -; as the objective of the following two ("Everything that is 'become' 'becomes' from a cause"). (2.b) "That which exists not from a cause is not 'become", the discovery of the Efficient Cause (In Tim.
} 
The first "demonstration" covers three lemma: 28b5, 28b6 - 8, and 28b8 - c2. In the context of this first "demonstration" (In Tim. I.275.3 - 296.12), Proclus establishes the thesis that the world is both "become and eternal" ( $\gamma \varepsilon v \eta$ tòv kaì ôv),12 that is to say, "become" according to essence and "eternal" according to time.

According to Proclus, Plotinus, on the one hand, and, subsequently, Porphyry and Iamblichus, share with Crantor the assignment to "generated" ( $\gamma \varepsilon v \eta \tau$ tóv) of a sense that does not refer to time, but only to the dependence of a cause.

"Crantor and his circle of exegetes of Plato, however, say that the cosmos is said to be generated ( $\gamma \varepsilon v \eta \tau o ̀ v)$ because it is brought into existence from another cause


$\left(\alpha \dot{\theta} \theta \pi_{0} \sigma \tau \alpha \tau o v\right)$. But Plotinus and the philosophers after him, Porphyry and Iamblichus, 13 say that it is being composite ( $\sigma 0 v v \theta \varepsilon \tau o ́ v)$ which in this context has been called generated and that the fact that it has been generated $(\dot{\alpha} \pi \mathrm{o} \gamma \varepsilon v v \tilde{\alpha} \sigma \theta \alpha \mathrm{l})$


trans. Runia and Share 2008, 127). ${ }^{14}$

Proclus attributes to Plotinus and his successors the thesis that "generated" equates at the same time to "composed being" and "generated being from a cause different to itself". Plotinus's innovation lies in adding to $\gamma \varepsilon v \eta \tau$ tóv the composed being, that is to say, in establishing an association between generation and composition.

III.

In Treatise 3 (III.1, On Destiny), one of the first drafted, Plotinus affirms that everything that is produced in the things that become ( $\gamma 1 \gamma v o$ $\mu \varepsilon v \alpha)$, but also in those that always are ( $\dot{\alpha} \varepsilon \dot{\text { o }} v \tau \alpha)$ - the three main hypostases ${ }^{15}$ - which do not always exercise

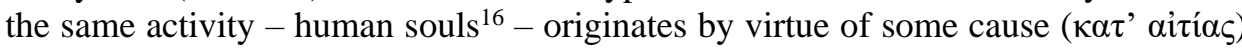
and the uncaused (ávaitıov) must not be admitted..$^{17}$ In this way, Plotinus applies the principle of causality both to beings who always are and to those who become.

For Plotinus, intelligible forms are both "generated" ( $\gamma \varepsilon v \eta \tau \alpha)$ and "ungenerated" $(\dot{\alpha} \gamma \varepsilon \dot{\varepsilon} \eta \eta \tau)$ : While they have a principle $(\dot{\alpha} \rho \chi \eta)$ ), they are generated; but, since this principle is not a temporal beginning, but "that they are forever" (öv $\tau \alpha \dot{\alpha} \varepsilon i ́)$, they are

I.258.12 ff., ad 28a4 - 6); of the other two, the discovery of the Model; and, finally, with the name of the World, the discovery of the Final Cause (In Tim. I.272.10 ff. [ad. 28b3 - 5]; see In Tim. I.226.22 ff.).

${ }^{12}$ Proclus, In Tim. I.276.27 (ad. 28 b6 - 8); 292.15 (ad. 28b8 - c2). See Lernould (2000, 69 - 70).

${ }^{13}$ Iamblichus, Fr. 32 Dillon.

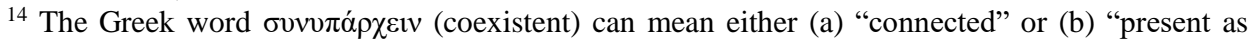
a subordinate". See Philips $(1997,180)$.

${ }^{15}$ See Plotinus, Treatise 3 (III.1) 1.8. Those that "always are" are the three primary levels of reality, i.e. the three main hypostases - the One, the Intelligence, and the Soul - (10 [V.1]). The One, the Intelligence, and the Soul are indissoluble and indestructible.

${ }^{16}$ See, e.g., Plotinus, Treatise 7 (V.4) 15 and 17.

${ }^{17}$ See Plotinus, Treatise 3 (III.1) $1.13-16$. 
also ungenerated (12 [II.4] $5.25-28) .{ }^{18}$ Therefore, intelligible forms are generated, but did not originate at a particular moment (33 [II.9] 3.12 - 13), as in Gnosticism, as a result of a mishap in the Pleroma, but are eternally dependent on something else (à $\dot{\varepsilon}$ $\pi \alpha \rho^{\prime}$ ö $\left.\lambda \lambda \mathrm{ov}\right)(12$ [II.4] 5.26-27).

"Things that are said to have come into being did not just come into being [at a par-

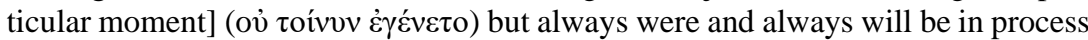

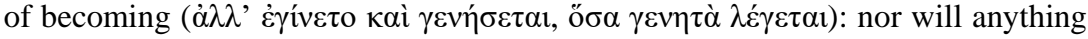

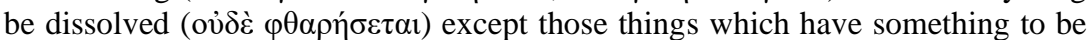
dissolved into that which has nothing into which it can be dissolved will not perish



Plotinus conceptually distinguishes between (1) ontological or causal dependence, which causes intelligible forms to be generated by coming from another higher level of reality, and (2) the generation of becoming, which also means corruption. The sensible world is eternal in the sense of no beginning or end, but perpetually becoming (12 [II.4] 5.27; 45 [III.7] 6.38 - 42).

In Plotinus, we can also distinguish two meanings of the term "ungenerated"

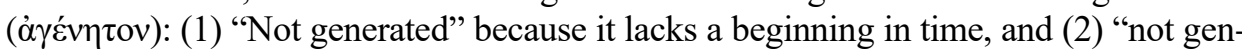
erated" because it is independent of a previous principle from which it comes. ${ }^{19}$ The first meaning is not the same as the second. Thus, the matter of the intelligible is not generated in the first meaning, since it has no beginning in time; however, it is generated in the second meaning, since it has a principle, the "first principle" and "otherness". ${ }^{20}$

But what happens if we apply this distinction between the two meanings of "ungenerated" for the matter of the intelligible world to the matter of the sensible world? The result is the same, because the matter of the sensible world is not generated in

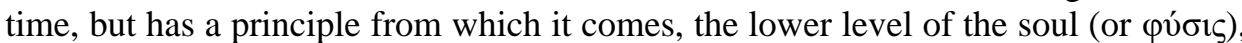
hence it is also generated. Although Plotinus does not expressly refer to the matter of the sensible world, we can apply the distinction between the two meanings of the term "ungenerated"; and thus, both the matter of the sensible world and the matter of the intelligible world are generated $(\gamma \varepsilon v \eta \tau \dot{\alpha})$, because they have a principle from which they come, and "ungenerated" ( $\dot{\alpha} \gamma \dot{\varepsilon} v \eta \tau \alpha)$, since they do not have a beginning in time. The relationship of matter with time, however, is different in the intelligible and the sensible world. Thus, if we continue to read the text quoted above, Plotinus distinguishes the sensible world, which becomes "forever", from the intelligible world, which exists "forever", since otherness, the constitutive principle of intelligible matter, also exists "forever" 21.

\footnotetext{
${ }^{18}$ See Narcy $(2005,425-426)$.

${ }^{19}$ On these two senses of "ungenerated", see O'Brien $(1991,37)$.

${ }^{20}$ See Plotinus, Treatise 12 (II.4) $5.24-26$.

${ }^{21}$ Plotinus, Treatise 12 (II.4] 5.25 - 28: "intelligible realities are originated ( $\left.\gamma \varepsilon v \eta \tau \grave{\alpha}\right)$ in so far as they

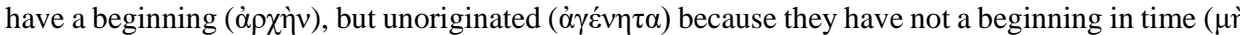

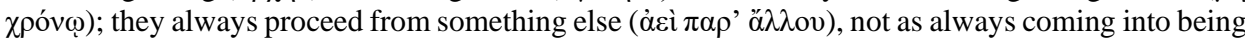


In the second book of Treatise 23 (VI.5, On the Presence of Being, One and the Same, Everywhere as a Whole), Plotinus takes up the distinction drawn in Timaeus $(27 \mathrm{~d} 6-28 \mathrm{a} 1)$ between "that which always is and has no becoming" and "that which is always becoming but never is" to interpret the doctrine of the participation of the sensible in intelligible forms, which constitutes the backdrop to the thesis of omnipresence and omniabsence of the intelligible being. ${ }^{22}$ Plotinus connects "that which always is" (Tim. 28a4) with the immutability of the Sophist (248a12). Since the intelligible being is immutable, it is "always with itself" (23 [VI.5] $3.1-5)$, that is to say, it does not experience the suffering characterised by "being in another", "being owned by another" (23 [VI.5] $3.5-12)$. Therefore, the intelligible being is "nowhere", since it needs neither a place nor a substrate to be in; and, similarly, is "everywhere", since particular things participate in it, since it is present in each one of them. ${ }^{23}$

IV.

In Sentence 14, Porphyry contrasts bodies with the incorporeal, wondering in what sense it can be said that they are "generated", since everything that is generated is generated from another (Sent. 13). For bodies, "generated" ( $\gamma \varepsilon v \eta \tau o ́ v)$ means to exist as a result of a composition; for incorporeal beings, on the other hand, "generated" means to depend on a cause. In this way, generation, understood to mean composition, is inseparable from death, understood to mean dissolution. However, nothing similar can happen in the case of incorporeal beings, which are neither born nor destroyed, that is to say, in the same way that they have not been generated temporarily, they cannot experience dissolution either. Thus, the soul, the intermediary between the sensible and the intelligible, can ascend, but it can also descend. If it descends, then it divides and its power decreases; if it rises, it is unified and its power increases (Sent. 11).

"Everything generated owes the cause of its generation to something else ( $\pi \tilde{\alpha} v$

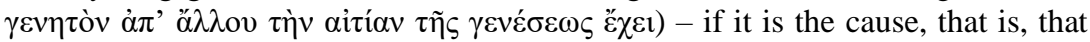
nothing is generated without a cause ( $\dot{\alpha} v \alpha \imath \tau i \omega \varsigma)$. But of things generated, such as have gained their existence through composition ( $\delta \grave{\alpha} \sigma v v \theta \varepsilon \dot{\sigma} \sigma \omega \varsigma)$ would be subject to dissolution $(\lambda v \tau \dot{\alpha})$, and thus to destruction ( $\varphi \theta \alpha \rho \tau \dot{\alpha})$; those, on the other hand, which, being simple and incomposite ( $\dot{\alpha} \pi \lambda \tilde{\alpha} \kappa \alpha \grave{~} \alpha \sigma v ́ v \theta \varepsilon \tau \alpha)$, have gained their existence while maintaining simplicity of subsistence, as they are indissoluble $(\ddot{\alpha} \lambda v \tau \alpha)$, are indestructible ( $\ddot{\alpha} \varphi \theta \alpha \rho \tau \alpha)$, but yet are said to be generated $(\gamma \varepsilon v \eta \tau \grave{\alpha})$, not through being composite ( $\sigma v \dot{v} \theta \varepsilon \tau \alpha)$, but through their being dependent on some

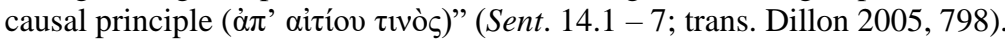

Thus, Porphyry defends the most radical point of view of the first Neoplatonists as regards the interpretation of the axiom of causation. For the philosopher of Tyre,

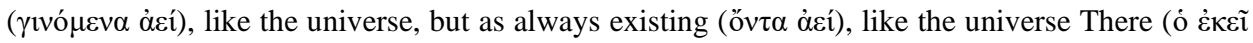

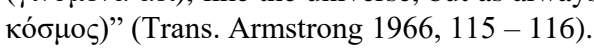

${ }^{22}$ See Plotinus, Treatise 23 (VI.5) 2.9 - 19; Porphyry, Sentences 38.9 - 10.

${ }^{23}$ See, for example, Proclus, The Elements of Theology, propositions 98, 86, 88, 108, 112, 122. For a commentary on prop. 112 and 122, see Dodds (1963, 257 ff. and 264 ff.). 
"generated" meant two things: (1) to depend on a cause and (2) to exist by virtue of a composition (Sent. 14.6 - 9). The first meaning corresponds to simple realities, intelligence and soul (14.9 - 10); to bodies, however, both meanings of the term correspond. That said, these two meanings are interconnected in two different ways: (1) from the point of view of extent, the first includes the second; but (2) from the point of view of comprehension, both meanings are juxtaposed, side by side. ${ }^{24}$ The concept of composition requires that of causality, since every composite presupposes the cause that brings together the components. ${ }^{25}$ Generate by composition is then equivalent to a kind of causality.

How does Porphyry explain, from the point of view of comprehension, this juxtaposition between causality and composition? To attempt to answer this question, it is necessary to turn to the distinction that Plato draws in Timaeus $(28 \mathrm{~b} 5-\mathrm{c} 2)$. Although the interpretation of this passage seeks to establish the compatibility between being generated and incorruptible, in Sentence 14, this compatibility is only valid with respect to the first meaning of "generated".

The hermeneutical key of certain Platonists focuses on preserving the exegesis of this passage of Timaeus from criticism directed at it by Aristotle. In his treatise $\mathrm{On}$ the Heavens (I.10.280a28 - 32), ${ }^{26}$ the Stagirite affirms that it is impossible to defend, as Plato proposes in Timaeus, that the world is generated and incorruptible. If it is said to be generated, it must be maintained that it is also corruptible. ${ }^{27}$ Consequently, and faced with this Aristotelian objection, a number of the members of the Platonic school sought to demonstrate that the assertion of the generation of the world does not signify

\footnotetext{
${ }^{24}$ The adverb $\delta \chi \tilde{\omega} \zeta$, "in two ways", indicates this juxtaposition: the two meanings are on the same

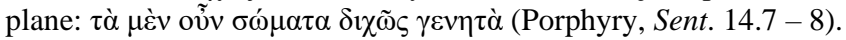

${ }^{25}$ See Proclus, In Tim. I.280.2 - ;4.

${ }^{26}$ See also Aristotle, De Caelo, I.10.279b26 - 33, and I.12.282b4.

${ }^{27}$ In De Caelo (I.10.279b4 - 280a35), Aristotle discusses "physical" foundations against those who argued that the world has a beginning but not an end. The main objective is clearly focused on the cosmology of Timaeus understood literally. In chapter 12 of Book I of De Caelo, Aristotle states that, contrary to Plato's thesis in Timaeus, a generated being is obligatorily corruptible, and, conversely, an ingenerated being is necessarily incorruptible. See Longo (1962, 312); see Federspiel (2017, 287, 312); see also Broadie (2009, esp. 29 - 33, 39 - 42). For Simplicius: "The argument seems to be directed mainly against Xenocrates and the Platonists (

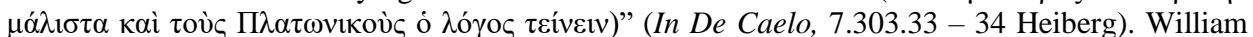
Moerbeke, in his Latin translation of Simplicius, On Aristotle On the Heavens: "Videtur quidem adversus Xenocratem maxime et adversus Platonicos sermo tendere, quia ex inordinato et fluctuoso genitum esse mundum aiun" (424.82 - 83 Bossier). On Xenocrates, see Fr. 54 Heinze (1892), and Fr. 73 - 78 Isnardi Parente (2012, 375 ff). On Aristotle's interpretation of the problem, see Plutarch, De animae procreatione in Platonis Timaeo 1013A-F; see Cherniss (1944, 421 ff., and 1976, 170); see also Claghorn (1954, 95 ff.). On Theophrastus' interpretation, see Fr. 241A: "Theophrastus however, in On the Opinions of the Natural Philosophers, says that the universe has an origin ( $\gamma \varepsilon v \eta \tau$ ìv) according to Plato, and makes his objections accordingly. But he (also) suggests that perhaps (Plato)

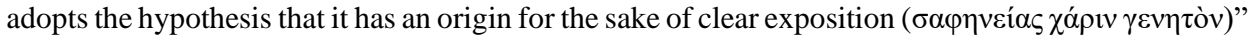
(trans. Fortenbaugh - Huby - Sharples - Gutas 1992, 430 - 431; see also Fr. 241B).
} 
its corruptibility. ${ }^{28}$ Indeed, to achieve their objective, the Platonists proposed a new meaning for "generated", different to having a beginning in time. ${ }^{29}$

In Sentence 14, Porphyry interconnects the two meanings of "generated" introduced by members of the Platonic school: according to Proclus, Crantor provides the first meaning of "generated", ${ }^{30}$ which appears in Sentence 14, and, in the second century AD, Taurus, as John Philoponus conveys in his treatise against Proclus, ${ }^{31}$ incorporates a new meaning close to the second meaning. For Taurus, the world is generated in the sense that it is possible to conceive it as composed of certain elements. According to this, from the interpretation of Taurus, the composition is not real, but rather corresponds to a way of conceiving the world as generated, that is to say, as a composite of qualities and from a first substrate.

The fragments of his Commentary on Timaeus preserved by Philoponus show that Taurus stood on the side of the Platonists who argued that the world was ungenerated and incorruptible..$^{32}$ In opposition to Atticus and Plutarch, he does not interpret the passage from Timaeus (28b7) literally: the world was not manufactured at a particular time. It is necessary to overcome the surface level of the letter and not interpret the terms "generated" ( $\gamma \varepsilon v \eta \tau o ́ v)$ and "starting-point" ( $\dot{\alpha} \rho \chi \eta ́)$ temporally.

In light of Taurus's proposal, Porphyry addresses the following question in Sentence 14: If the composition were real, would the decomposition of the world be possible? As we know again thanks to Philoponus (De aeternitate mundi contra Proclum 148.9 - 15; 154.23 - 26), Porphyry, in his commentary on Timaeus, considers the second definition as the most appropriate: "generated" is that which is conceived as composed specifically of matter and form. However, Philoponus's treatise does not convey Porphyry's interpretation of the first meaning of "generated" introduced by Crantor, nor in what way these two meanings interconnect. We have to turn to Proclus (In Tim. I.277.10 - 14) again to discover that Plotinus, Porphyry and Iamblichus innovated with respect to Crantor's thesis by defending the second meaning. But these first Neoplatonists would also admit that the composed is also characterised by dependence on a cause (In Tim. I.277.10 - 14). Consequently, for these three Neoplatonists, the second meaning signifies the first.

${ }^{28}$ Porphyry, in the context of a similar argument, also immediately addresses the Aristotelian objection (In Tim. II, Fr. 51.103 - 111 Sodano = Proclus, In Tim. I.395.1 - 10). See Gleede (2009, $286-287)$.

${ }^{29}$ See Proclus, In Tim. I.279.30 - 32; see also 276.30 - 277.3. See Festugière $(1967,122)$.

${ }^{30}$ Proclus, In Tim. I.277.8 - 10. See supra, n. 14.

${ }^{31}$ See John Philoponus, De aeternitate mundo contra Proclum 146.13 - 20: "Also described as 'generated' ( $\gamma \varepsilon v \eta \tau o ̀ v)$ are things that are notionally composite ( $\sigma 0 ́ v \theta \varepsilon \tau o v)$, even if they have not [actually] been put together. In this sense the middle note [of the scale] is composed of the highest

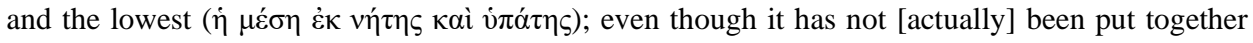
[from them], we detect in it the value that they have relative to each other. And the same applies to

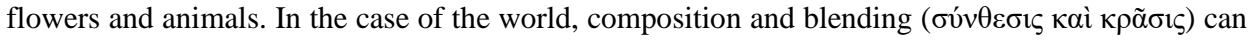

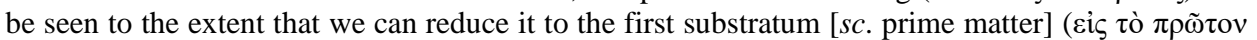

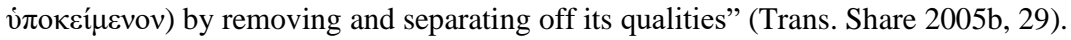

32 On the interpretation of Taurus' Timaeus 28b7, see Baltes $(1976,105-121)$, Verrycken (1997, 283 - 317), Kühn (2005, 423 - 424), see also Karamanolis (2006, 179 - 184). 
That said, it would seem that in Sentence 14 Porphyry points out that there are two different meanings of "generated", while in Proclus the second meaning signifies the first, which it should replace. However, the explanation rests on the same basis: these are two meanings that in the history of the interpretation of Timaeus $(27 \mathrm{~d} 6$ - 28a1) were proposed separately, and which both Porphyry and Proclus tried to articulate.

\section{Conclusions}

In Timaeus, Plato sets out the axiom of causality after the exposition of an ontology in which he opposes being and becoming, between "that which always is and has no becoming" and "that which is always becoming but never is". Generation and destruction are inseparable notions: that which is generated is susceptible to destruction, and that which is susceptible to destruction is generated. So Plato alludes to the eventuality of the destruction of the universe, which is generated, although later rejected (Tim. $38 \mathrm{~b})$. The changes that come with the notion of becoming - generation and corruption - precisely require that there be a principle of causality: such as that which becomes, since it is generated and destroyed, but never truly is.

Plotinus does not extend the principle of causality beyond the sensible. ${ }^{33} \mathrm{He}$ does not depart much, therefore, from the Platonic proposal in Timaeus: where Plato makes a distinction between becoming, which needs a cause, and being, which, as it is immutable, "is ceaseless", and has no cause. However, in Plotinus, the distinction between ontological dependence - through which intelligible forms are generated - and becoming is not as clearly settled as in Porphyry.

Porphyry's interpretation in Sentence 14 modifies the Platonic principle of causality, as it appears in Timaeus (28a), where that which becomes, while not truly, is the object of opinion and is not intelligible. By contrast, the statement of the principle of causality in Porphyry does not come after the ontological exposition, as in Plato, but rather precedes it. Thus, the field of the "generated" ( $\gamma \varepsilon v \eta \tau o ́ v)$ extends beyond the sensible in such a way that it applies the principle of causality to the field of the supersensible, beyond becoming (i.e., the Soul and the Intelligence, generated from and by the One).

Instead of opposing being and becoming, like Plato, Porphyry introduces a distinction in the field of the "generated" in such a way that it can no longer coincide with either the sensible or becoming. Even assuming that everything that is composed, and therefore also susceptible to decomposition, is exposed to destruction, some beings are "generated" ( $\gamma \varepsilon v \eta \tau \alpha ́)$ not because they integrate the cycle of that which is generated and that which is susceptible to destruction, but just because they depend on a cause.

In this way, Porphyry expands causality to the being and the intelligible. For Porphyry, the Platonic axiom of causality: everything that generates (= generated) necessarily generates due to a cause ${ }^{34}$ is only valid if the meaning of "generated"

\footnotetext{
${ }^{33}$ See Plotinus, Treatise 3 (III.1) $1.12-15$.

34 See Plato, Tim. 28c2 - 3: "Further, we maintain that, necessarily, that which comes to be must

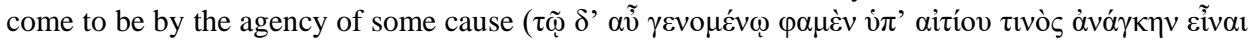


( $\gamma \varepsilon v \eta \tau$ tóv) is applied to non-composed, and therefore incorporeal, realities. In the Neoplatonic distinction, these realities, being indestructible (Sent. 14.6), are not in the range of "that which is always generated and never is", but of "that which always is and is not generated", that is to say, of "that which is without ceasing to be". This imbalance with respect to the literal meaning of Timaeus is compatible with the henological-processional architecture of Neoplatonism, where ontological dependence concerns everything that is inferior to the One-Good and, therefore, prior to the generation of the sensible: hypostasis and beings, different and prior to becoming.

\section{Bibliography}

ARMSTRONG, A. H. (1966): Plotinus. Ennead II. Cambridge, Mass. - London: Harvard University Press - William Heinemann Ltd.

BALTES, M. (1976): Die Weltentstehung des platonischen Timaios nach den Antiken Interpreten. Teil I. Leiden: Brill.

BALTES, M. (1978): Die Weltenstehung des platonischen Timaios nach den antiken Interpreten. Teil II: Proklos. Leiden: Brill.

BOSSIER, F. (2004): Simplicius. Commentaire sur le Traité du Ciel d'Aristote. Traduction de Guillaume de Moerbeke. Leuven: Leuven University Press.

BRISSON, L. (ed.) (2005): Porphyre. Sentences. 2 vols. Paris: Vrin.

BROADIE, S. (2009). The Possibilities of Being and Not-Being in De Caelo 1.11 - 12. In: Bowen, A. - Wildberg, C. (eds.): New Perspectives on Aristotle's De caelo. Leiden: Brill, 29 - 50.

BURNET, J. (1900 - 1907): Platonis Opera. 5 vols. Oxford: Clarendon Press.

CHERNISS, H. (1944): Aristotle's Criticism of Plato and the Academy (Volume I). Baltimore: Johns Hopkins University Press [= reprinted, New York: Russell \& Russell, 1962].

CHERNISS, H. (1976): Plutarch's Moralia (Volume XIII, Part I: 999C-1032F and Part II: 1033A - 1086B). Cambridge, Mass. - London: Harvard University Press - William Heinemann Ltd.

CLAGHORN, G. S. (1954): Aristotle's Criticism of Plato's Timaeus. The Hague: Nijhoff.

DIEHL, E. (1903 - 1906): Procli Diadochi In Platonis Timaeum commentaria. 3 vols. Leipzig: Teubner [= reprinted, Amsterdam: Hakkert, 1965].

DILLON, J. (1973): Iamblichi Chalcidensis In Platonis dialogos commentariorum fragmenta. Leiden: Brill.

DILlON, J. (2005): Porphyry, Pathways to the Intelligible. In: Brisson, L. (ed.): Porphyre. Sentences. Vol. 2. Paris: Vrin, $795-835$.

DODDS, E. R. (1963 [1933]): Proclus. The Elements of Theology. Oxford: Clarendon Press.

FEDERSPIEL, M. (2017): Aristote. Du ciel. Paris: Les Belles Lettres.

FESTUGIÈRE, A.-J. (1967): Proclus. Commentaire sur le Timée. Vol. 2. Paris: Vrin.

FORTENBAUGH, W. - HUBY, P. - SHARPLES, R. - GUTAS, D. (eds.) (1992): Theophrastus of Eresus. Sources for His Life, Writings, Thought and Influence. Part One. Life, Writings, Various Reports, Logic, Physics Metaphysics, Theology, Mathematics. Leiden: Brill.

GLEEDE, B. (2009): Platon und Aristoteles in der Kosmologie des Proklos: ein Kommentar zu den 18 Argumenten für die Ewigkeit der Welt bei Johannes Philoponos. Tübingen: Mohr Siebeck.

HEIBERG, J. L. (1894): Simplicii in Aristotelis de caelo commentaria. In: Commentaria in Aristotelem Graeca 7. Berlin: Reimer.

HEINZE, R. (1892): Xenokrates: Darstellung der Lehre und Sammlung der Fragmente. Stuttgart: Teubner [= reprinted, Hildesheim: G. Olms, 1965].

$\gamma \varepsilon v \varepsilon ́ \sigma \theta \alpha 1)$ " (Trans. Zeyl 1997, 1236). Plato returns frequently to the principle of causality in Phaedo 98c, 99b; Philebus 27b; Timaeus 29d, 46e, 57e, 68e, 69a, 87e, 38d, 44c, 46d, 64d; and Laws X.891e. 
HENRY, P. - SCHWYZER, H.-R. (1964 - 1982): Plotini Opera. 3 vols. Oxford: Clarendon Press.

ISNARDI PARENTE, M. (1982 [2012]): Senocrate-Ermodoro: Frammenti. Naples: Bibliopolis [new revised edition by T. Dorandi, Pisa: Edizioni della Normale, 2012].

KARAMANOLIS, G. E. (2006): Plato and Aristotle in Agreement? Platonists on Aristotle from Antiochus to Porphyry. Oxford: Clarendon Press.

KÜHN, W. (2005): Geneton. In: Brisson, L. (ed.): Porphyre. Sentences. Vol. 2. Paris: Vrin, 423 - 424.

LAMBERZ, E. (1975): Porphyrii Sententiae ad intelligibilia ducentes. Leipzig: Teubner.

LEGGATT, S. (1995): Aristotle: On the Heavens I and II. Warminster: Aris \& Phillips.

LANG, H. S. - MACRO, A. D. - McGINNIS, J. (2001): Proclus: On the Eternity of the World (De aeternitate mundi). Berkeley - Los Angeles: University of California Press.

LERNOULD, A. (2000): La Divisio Textus du Timée dans l'In Timaeum de Proclus (sur la physique pythagoricienne du Timée selon Proclus). In: Neschke-Hentschke, A. (ed.): Le Timée de Platon. Contributions à l'histoire de sa réception/Platos Timaios. Beiträge zu seiner Rezeptionsgeschichte. Louvain - Paris: Peeters, $63-93$.

LONGO, O. (1962): Aristotele. De Caelo. Firenze: Sansoni.

MORAUX, P. (1965): Aristote. Du ciel. Paris: Les Belles Lettres.

NARCY, M. (2005): Anertesthai. In: Brisson, L. (ed.): Porphyre. Sentences. Vol. 2. Paris: Vrin, $424-426$.

MUELLER-JOURDAN, P. (2011): Gloses et commentaire du livre XI du Contra Proclum de Jean Philopon: autour de la Matière première du monde. Leiden: Brill.

O'BRIEN, D. (1991): Plotinus on the Origin of Matter an Exercise in the Interpretation of the Enneads. Naples: Bibliopolis.

PHILLIPS, J. F. (1997): Neoplatonic Exegesis of Plato's Cosmogony (Timaeus 27c - 28c). Journal of the History of Philosophy, 35 (2), 173 - 197.

RABE, H. (1899): Ioannes Philoponus: De aeternitate mundi contra Proclum. Leipzig: Teubner [= reprinted, Hildesheim: Olms, 1963].

RIVAUD, A. (1925): Platon. Euvres complètes, X: Timée-Critias. Paris: Les Belles Lettres.

ROSÁN, L. J. (1949): The Philosophy of Proclus. The Final Phase of Ancient Thought. New York: Cosmos.

RUNIA, D. T. - SHARE, M. (2008): Proclus. Commentary on Plato's Timaeus. Vol. II, Book 2: Proclus on the Causes of the Cosmos and its Creation. Cambridge: Cambridge University Press.

SEGONDS, A. P. (1992): À propos d'une page du De aeternitate mundi de Jean Philopon. In: Gou-


sagesse”. Hommage à Jean Pépin. Paris: Institut d'Études augustiniennes, 461 - 479.

SHARE, M. (2005a): Philoponus: Against Proclus On the Eternity of the World 1 - 5. London Ithaca - NY: Duckworth - Cornell University Press.

SHARE, M. (2005b): Philoponus: Against Proclus On the Eternity of the World $6-8$. London Ithaca - NY: Duckworth - Cornell University Press.

SHARE, M. (2010): Philoponus: Against Proclus On the Eternity of the World 9 - 11 London Ithaca - NY: Duckworth - Cornell University Press.

SODANO, A. R. (1964): Porphyrii in Platonis Timaeum commentariorum fragmenta. Napoli: Istituto della Stampa.

WILBERDING, J. (2006): Philoponus: Against Proclus On the Eternity of the World 12 - 18. London - Ithaca - NY: Duckworth - Cornell University Press.

VERRYCKEN, K. (1991): La psychogonie platonicienne dans l'œuvre de Philopon. Revue des sciences philosophiques et théologiques, 75 (2), 211 - 234.

VERRYCKEN, K. (1997): Philoponus' Interpretation of Plato's Cosmogony. Documenti e Studi sulla Tradizione Filosofica Medievale, 8, 269-318.

WHITTAKER, J. - LOUIS, P. (1990): Alcinoos. Enseignement des doctrines de Platon. Paris: Les Belles Lettres. 
ZAMORA CALVO, J. M. (2010): Platón. Timeo. Edición bilingüe, con notas y anexos de L. Brisson. Madrid: Abada.

ZEYL, D. J. (1997): Plato, Timaeus. In: Cooper, J. M. - Hutchinson, D. S. (eds.): Plato, Complete Works. Indianapolis, Cambridge: Hackett Publishing Company, 1224 - 1291.

This paper benefited from the support of two Spanish R\&D projects: HAR2017-83613-C2-2-P and H2019/HUM-5714, and is part of the activities of the UAM Research Group: Influences of Greek Ethics on Contemporary Philosophy (Ref. F-055).

José María Zamora Calvo

Departamento de Filosofía

Facultad de Filosofía y Letras

Universidad Autónoma de Madrid

Campus de Cantoblanco

E-28049 Madrid

Spain

e-mail: jm.zamora@uam.es

ORCID ID: https://orcid.org/0000-0001-7101-2234 